University of Nebraska - Lincoln

DigitalCommons@University of Nebraska - Lincoln

USDA National Wildlife Research Center - Staff Publications
U.S. Department of Agriculture: Animal and Plant Health Inspection Service

July 2002

\title{
Safe efficacy of three strychnine alkaloid bait concentrations for hand-baiting control of plains pocket gophers
}

\author{
Craig A. Ramey \\ Wildlife Services, National Wildlife Research Center, US Department of Agriculture, Animal and Plant \\ Health Inspection Service \\ George H. Matschke \\ Wildlife Services, National Wildlife Research Center, US Department of Agriculture, Animal and Plant \\ Health Inspection Service \\ Paul L. Hegdal \\ Wildlife Services, National Wildlife Research Center, US Department of Agriculture, Animal and Plant \\ Health Inspection Service \\ Geraldine R. McCann \\ Wildlife Services, National Wildlife Research Center, US Department of Agriculture, Animal and Plant \\ Health Inspection Service \\ Richard M. Engeman \\ USDA-APHIS-Wildlife Services, s_r100@yahoo.com
}

Follow this and additional works at: https://digitalcommons.unl.edu/icwdm_usdanwrc

Part of the Environmental Sciences Commons

Ramey, Craig A.; Matschke, George H.; Hegdal, Paul L.; McCann, Geraldine R.; and Engeman, Richard M., "Safe efficacy of three strychnine alkaloid bait concentrations for hand-baiting control of plains pocket gophers" (2002). USDA National Wildlife Research Center - Staff Publications. 491.

https://digitalcommons.unl.edu/icwdm_usdanwrc/491

This Article is brought to you for free and open access by the U.S. Department of Agriculture: Animal and Plant Health Inspection Service at DigitalCommons@University of Nebraska - Lincoln. It has been accepted for inclusion in USDA National Wildlife Research Center - Staff Publications by an authorized administrator of DigitalCommons@University of Nebraska - Lincoln. 


\title{
Safe efficacy of three strychnine alkaloid bait concentrations for hand-baiting control of plains pocket gophers
}

\author{
Craig A. Ramey ${ }^{2}$, George H. Matschke, Paul L. Hegdal, Geraldine R. McCann and \\ Richard M. Engeman
}

Wildlife Services, National Wildlife Research Center, US Department of Agriculture, Animal and Plant Health Inspection Service, 4101 LaPorte Avenue, Fort Collins, CO 80521-2154, USA

Available online 7 November 2001.

\begin{abstract}
In November 1990, field efficacy studies using milo baits formulated with $0.35 \%$, $0.75 \%$, or $1.30 \%$ strychnine alkaloid were compared to a placebo $(0.0 \%$ strychnine $)$ for controlling plains pocket gophers (Geomys bursarius) near Pleasanton, Texas. These data were required by the US Environmental Protection Agency (EPA) as partial fulfillment for the maintenance of the rodenticide registrations of the US Department of Agriculture. Each of four treatment units (TUs) within a block (2) was randomly assigned one of the four baits. Within each TU, 15 gophers were captured (balanced roughly for gender) and instrumented with radio transmitters. Following a pretreatment acclimation averaging 4.1 days, bait $(4 \mathrm{~g})$ was placed in active pocket gopher burrows by hand-baiting. Pocket gopher mortality was measured by monitoring the fate of radio-equipped pocket gophers $(n=123)$ both pretreatment and posttreatment. Lack of gopher movement on two consecutive days indicated death, and the carcass was retrieved. Strychnine mortality was based on chemical analyses of carcasses, and it occurred in $0.0 \%, 66.7 \%, 96.3 \%$, and $89.7 \%$ of gophers from the $0.0 \%, 0.35 \%, 0.75 \%$ and $1.30 \%$ TUs, respectively. Natural mortality was $7 \%$ on the placebo TUs. All three strychnine treatments provided significantly increased mortality over the placebo $(P<0.0001)$ using Fisher's exact test for paired comparisons. A difference in gopher mortality occurred between the $0.32 \%$ and $0.77 \%$ strychnine treatments $(P=0.003)$, but not between the other comparisons $(0.32 \%$ vs $1.30 \%$, $P=0.18$ and $0.77 \%$ vs. $1.30 \%, P=0.24)$. Gopher carcasses recovered posttreatment indicated 68 of $86(79.1 \%)$ had strychnine alkaloid residues. The non-target strychnine hazard (using leastsquares means) by treatment were $4.85 \mathrm{ppm}(0.35 \%), 8.04 \mathrm{ppm}(0.75 \%)$, and $9.47 \mathrm{ppm}(1.30 \%)$. Carcass residue differences were not detected among strychnine treatments $(F=2.48, \mathrm{df}=2,3$, $P=0.23)$. Fortunately, non-target exposure was greatly decreased because all carcasses with strychnine residues were recovered underground at a mean depth of $0.51 \mathrm{~m}(\mathrm{SE}=0.027$, range 0.15-1.17 m). Placebo-baited TUs had 27 survivors and 2 deaths from unknown causes. None had detectable strychnine levels. No non-target mortalities were documented during carcass searches and radio-tracking activities.
\end{abstract}

Author Keywords: Safe efficacy; Strychnine; Hand-baiting; Pocket gophers

Published in International Biodeterioration \& Biodegradation

Volume 49, Issues 2-3, 2002, Pages 139-143 


\title{
Safe efficacy of three strychnine alkaloid bait concentrations for hand-baiting control of plains pocket gophers
}

\author{
Craig A. Ramey *, George H. Matschke, Paul L. Hegdal, Geraldine R. McCann, \\ Richard M. Engeman
}

Wildlife Services, National Wildlife Research Center. US Department of Agriculture. Animal and Plant Health Inspection Sertice. 4101 LaPorte Aienue. Fort Collins, CO 80521-2154, USA

\begin{abstract}
In November 1990 , field efficacy studics using milo baits formulated with $0.35 \%, 0.75 \%$, or $1.30 \%$ strychnine alkaloid were compared to a placebo $(0.0 \%$ strychnine ) for controlling plains pocket gophers (Geomvs bursarius) near Pleasanton, Texas. These data were required by the US Environmental Protection Agency (EPA) as partial fulfillment for the maintenance of the rodenticide registrations of the US Department of Agriculture. Each of four treatment units (TUs) within a block (2) was randomly assigned one of the four baits. Within each TU, 15 gophers were captured (balanced roughly for gender) and instrumented with radio transmitters. Following a pretreatment acclimation averaging 4.1 days, bait $(4 \mathrm{~g})$ was placed in active pocket gopher burrows by hand-baiting. Pocket gopher mortality was measured by monitoring the fate of radio-equipped pocket gophers $(n=123)$ both pretreatment and posttreatment. Lack of gopher movement on two consecutive days indicated death, and the carcass was retrieved. Strychnine mortality was based on chemical analyses of carcasses, and it occurred in $0.0 \%, 66.7 \%, 96.3 \%$, and $89.7 \%$ of gophers from the $0.0 \%, 0.35 \%, 0.75 \%$ and $1.30 \%$ TUs, respectively. Natural mortality was $7 \%$ on the placebo TUs. All three strychnine treatments provided significantly increased mortality over the placebo $(P<0.0001)$ using Fisher's exact test for paired comparisons. A difference in gopher mortality occurred between the $0.32 \%$ and $0.77 \%$ strychnine treatments $(P=0.003)$, but not between the other comparisons $(0.32 \%$ vs $1.30 \%, P=0.18$ and $0.77 \%$ vs. $1.30 \%, P=0.24)$. Gopher carcasses recovered posttreatment indicated 68 of $86(79.1 \%)$ had strychnine alkaloid residues. The non-target strychnine hazard (using least-squares means) by treatment were $4.85 \mathrm{ppm}(0.35 \%), 8.04 \mathrm{ppm}(0.75 \%)$, and $9.47 \mathrm{ppm}(1.30 \%)$. Carcass residue differences were not detected among strychnine treatments $(F=2.48$, df $=2,3, P=0.23)$. Fortunately, non-target exposure was greatly decreased because all carcasses with strychnine residues were recovered underground at a mean depth of $0.51 \mathrm{~m}(\mathrm{SE}=0.027$, range $0.15-1.17 \mathrm{~m})$. Placebo-baited TUs had 27 survivors and 2 deaths from unknown causes. None had detectable strychnine levels. No non-target mortalities were documented during carcass scarches and radio-tracking activitics. (C) 2002 Elsevier Science Ltd. All rights reserved.
\end{abstract}

Keywords: Safe efficacy; Strychnine; Hand-baiting; Pocket gophers

\section{Introduction}

Strychnine alkaloid is probably the most widely used pesticide in the world (Buck, 1991). In the United States, it is registered as an acute rodenticide by the Environmental Protection Agency (EPA) for underground control of pocket gophers (US Department of Agriculture, USDA, 1994). Strychnine alkaloid has been registered (Ramey et al., 1994) according to requirements outlined by the EPA in their March 10, 1989 Strychnine Settlement Agreement and later, in the Reregistration Eligibility Decision (US Environmental Protection Agency, USEPA, 1996). Four

\footnotetext{
${ }^{*}$ Corresponding author.
}

pocket gopher labels are registered by USDA $\backslash$ APHIS for strychnine alkaloid use under this agreement: two $0.50 \%$ labels for application by burrow builder (56228-11 and 56228-12) and two $0.50 \%$ labels for hand-baiting (56228-19 and 56228-20). In the Strychnine Settlement Agreement, the EPA required the USDA to submit additional efficacy data from both laboratory and field studies using the plains pocket gopher.

The National Wildlife Research Center (NWRC) designed laboratory studies to provide a range of concentrations of strychnine alkaloid baits for field testing and to identify the lowest effective concentration. A 3-day no-choice test was conducted with the plains pocket gopher using nine concentrations strychnine alkaloid on oat groat baits ranging from $0.10 \%$ to $1.51 \%$ to find the lowest $100 \%$ 
effective concentration (G.H. Matschke, NWRC, unpublished data, 1989). The most effective concentrations were $0.65 \%(96 \%$ mortality) and those concentrations greater than $1.3 \%$ (100\% mortality). A 1990 efficacy study, using strychnine alkaloid on milo baits applied underground with a burrow builder, was conducted with the plains pocket gopher in Texas (G.H. Matschke, NWRC, unpublished data, 1990). They used the open-hole method of Richens (1967) to measure pocket gopher activity and to estimate mortality. Mortality was $87.2 \%, 94.4 \%$, and $91.1 \%$ for the $0.35 \%, 0.75 \%$, and $1.30 \%$ nominal concentrations, respectively. Activity also declined $16.8 \%$ on the placebo plots $(0.0 \%$ strychnine $)$. Overall, the three strychnine concentrations were different from the placcbo bait $(P<0.001)$, but they were not different from one another $(P>0.05)$. Knowing that these results exceeded EPA's 70\% rodenticide efficacy standard for field trials (Schneider and Hitch, 1982 ), these three strychnine concentrations were examined in the current study (G.H. Matschke, NWRC, unpublished data, 1991). Our objective was to compare the effectiveness of hand-baiting with $0.35 \%, 0.75 \%$, or $1.30 \%$ concentrations of strychnine alkaloid milo baits for controlling plains pocket gophers.

\section{Materials and methods}

\subsection{Study site}

The study site was located near Pleasanton, Atascosa County, Texas. Two blocks (I and II), each containing four TUs were established in a mixed grass/forb habitat that supported pocket gophers. TUs averaged 3.2 ha $(\mathrm{SE}=1.3$, range $1.8-5.8$ ) and were separated by a minimum distance of $100 \mathrm{~m}$. Flags were used to define TU boundaries. Within each block, one of the four strychnine alkaloid bait concentrations $(0.0 \%, 0.35 \%, 0.75 \%$, and $1.30 \%)$ was randomly assigned to each TU prior to baiting.

\subsection{Bait formulation}

Collaborating scientists at NWRC prepared the strychnine treated and placebo baits. Strychnine alkaloid concentrate, an adhesive (Alcolec-S), and milo grain were used to prepare the strychnine baits. Placebo bait was prepared in the same manner except that strychnine alkaloid was omitted. Chemists at NWRC determined the technical strychnine alkaloid (CAS No. 57-24-9) was 96.7\% pure. After the three strychnine baits $(0.35 \%, 0.75 \%$, and $1.30 \%)$ and the placebo $(0.0 \%)$ were formulated, the four concentrations were verified by sampling and assaying. The analytical procedure for bait analysis followed NWRC's validated method (M.J. Goodall, unpublished Method 24B, 1990). The nominal $0.35 \%, 0.75 \%$, and $1.30 \%$ strychnine baits assayed as follows: $0.32 \%(\mathrm{SE}=0.006), 0.77 \%(\mathrm{SE}=0.006)$, and $1.30 \%(\mathrm{SE}=0.005)$, respectively. The $0.0 \%$ placebo bait assayed at $0.0 \%$ strychnine alkaloid. The nominal concentrations were used throughout this report, recognizing that the actual concentrations deviated to a minor degree.

\subsection{Bait application}

On November 13, 1990, the assigned bait was applied by hand to each of the four TUs in block I in the following order: $0.00 \%, 0.35 \%, 0.75 \%$, and $1.30 \%$, respectively. The same procedures were used on November 19, 1990 , to each of the four TUs in block II. Bait was applied systematically to ensure that each active pocket gopher burrow system received bait. Specifically, each burrow system was located with a probe and baited with $4 \mathrm{~g}$ of bait using a calibrated dipper. The bait was sealed in the burrow with tissue paper, and the tissue paper was covered with soil and marked with a flag. Bait was similarly placed in at least four additional locations in proximity to the initial location. Bait $(\mathrm{kg})$ applied per hectare was $0.335,0.370,0.465$, and 0.435 for $0.0 \%, 0.35 \%, 0.75 \%$ and $1.30 \%$ TUs, respectively. At the study's conclusion, flags were counted to determine the number of bait locations used for each strychnine alkaloid concentration ranging from lowest $(0.0 \%)$ to highest $(1.30 \%)$, respectively $(436,688,493$, and 686$)$. To reduce error, people were assigned to only one task (baiting or probing).

\subsection{Efficacy estimation}

\subsubsection{Pretreatment}

On each of eight TUs, about 15 gophers were live-trapped and instrumented (balanced roughly for gender). We captured 62 gophers on Block I on November 7, 1990, and 61 gophers on Block II, 7 days later. Each gopher was anesthetized with Metafane (methoxyflurane, 2,2dichloro-1,1-difluroethyl methyl ether) (Mallinckrodt Veterinary, Inc., Mundelein, IL), sexed (42\% males), weighed, and fitted with a 164,166 or $167 \mathrm{MHz}$ transmitter $(6.5 \mathrm{~g})$ (Denver Wildlife Research Center, Denver Federal Center, Denver, CO). After recovery from anesthesia, each gopher was released at its capture site and thereafter tracked daily using a portable radio receiver (Custom Electronics, 2009 Silver Court West, Urbana, IL). Each location was marked with a flag. The average number of days tracked pretreatment was $4.09(\mathrm{SD}=1.02)$.

\subsubsection{Postreatment}

After applying the bait, all human activity ceased on each block until late evening when all TUs were checked for gopher carcasses on the surface of the ground. Each radio-equipped gopher was located on Day 2, beginning at mid-day. If a gopher moved, the new position was recorded and flagged. On Days 3-7, all radio-equipped pocket gophers were located at least once a day. Lack of gopher movement on two consecutive days indicated that the gopher was 
dead ( $100 \%$ accuracy). Its carcass was recovered by excavation, and the depth of each excavated carcass was measured and recorded. On Day 3, we began recovering carcasses and this continued through Day 7. On Day 8, radio-equipped survivors were retrapped with MacAbec traps for recovery of the transmitters and carcasses. Seven of nine survivors that evaded traps were later recovered by fumigating the burrow systems. All recovered carcasses were weighed, checked for milo bait in their cheek pouches (none was found), and frozen for later residue analysis.

\subsubsection{Statistical analysis}

Because the mortality data from blocks I and II for each strychnine concentration were not different $(P>0.99)$, they were combined for additional mortality comparisons using Fisher's Exact Test (SAS Institute, 1966). Mortality of all strychnine alkaloid concentrations were compared: $0.35 \%$ vs. $0.75 \%, 0.35 \%$ vs. $1.30 \%$, and $0.75 \%$ vs. $1.30 \%$.

Each recovered gopher was also analyzed for strychnine residue following NWRC's validated method (Kimball, unpublished Method 7c, 1990). Strychnine residues (ppm) in carcasses were analyzed using PROC GLM analysis of variance (ANOVA), with TU nested within strychnine-bait concentrations used as the error term (SAS Institute, 1966).

\section{Results}

Natural mortality occurred with five $(4.1 \%)$ of the 123 radio-equipped gophers during the pretreatment radio-tracking period. Also, when radio-tracking on the evening of the day bait was applied in block I, we located on surface of the ground one additional radio-equipped pocket gopher apparently killed by a cat (Felis domesticus). Upon later chemical analysis of this carcass, strychnine residue if present was below the level of detection $(<0.2 \mathrm{ppm})$. Therefore, this gopher was not considered to have been killed by the strychnine treatment. These 6 deaths and the two gophers not recovered posttreatment were excluded from the study $(n=115)$.

Movements of radio-equipped pocket gophers declined two days after baiting the strychnine TUS. We recovered, 86 radio-equipped gophers from the strychnine TUs during Days 3-8. Of these, 75 died and 11 survived. Eight of the survivors ( 7 males: 1 female) came from the $0.35 \%$ TUs and 3 females came from the $1.30 \%$ TUs. Block I had $1(7 \%), 11(73 \%), 12(100 \%)$, and $12(86 \%)$ pocket gophers deaths; whereas, block II had 1 (7\%) $11(73 \%)$, $15(100 \%)$, and $14(93 \%)$ pocket gophers deaths on the $0.0 \%, 0.35 \%, 0.75 \%$, and $1.30 \%$ TUs, respectively.

All three strychnine alkaloid concentrations provided increased mortality over the placebo $(P<0.0001)$. Paired comparisons between strychnine alkaloid treatments indicated that a mortality difference did occur between the $0.32 \%(66.7 \%$ died $)$ and $0.77 \%(100.0 \%$ died $)$ strychnine concentrations $(P=0.003)$, but not between the other comparisons $(0.32 \%$ vs. $1.30 \%, P=0.18$ and $0.77 \%$ vs. $1.30 \%, P=0.24)$.

Carcass residues of gophers removed from three strychnine TUs indicated that 68 of $86(77.3 \%)$ pocket gopher carcasses were positive for strychnine alkaloid. Mean least-squares carcass residues for the $0.35 \%, 0.75 \%$, and $1.30 \%$ concentrations were $5.03,8.04$, and $9.47 \mathrm{ppm}$, respectively (Table 1). Seven carcasses yielded no data, because of chromatographic interference from a peak from an unknown co-cluting compound may have masked the strychnine alkaloid peak. For 10 of the 11 gophers that survived treatment, strychnine alkaloid, was below the level of detection (LOD). The 11 th surviving pocket gopher contained $0.9 \mathrm{ppm}$ strychnine yielding a $4.85 \mathrm{ppm}$ non-target strychnine hazard for the $0.35 \%$ TUs. All 29 pocket gophers from placebo TUs did not have strychnine residues, and they had no milo bait in their cheek pouches.

Differences were not detected in strychnine alkaloid carcass residues among strychnine treatments $(F=2.48$, df $=$ $2,3, P=0.23$ ). All 75 pocket gophers that died on strychnine TUs were excavated either in their nests or burrow systems. Mean (SE) depth of recovery was $0.51 \mathrm{~m}(\mathrm{SE}=0.027$, range $0.15-1.17 \mathrm{~m}$ ). During posttreatment radio-tracking, excavating, and trapping activities, no unmarked pocket gophers or non-target wildlife carcasses were located.

\section{Discussion}

We found no single strychnine concentration to be statistically superior to the other two concentrations for controlling the plains pocket gopher. Two unpublished studies on strychnine had similar results (Table 2). Variations in pocket gopher mortality among different strychnine concentrations have been documented previously (Tickes et al., 1982; Tickes, 1983). Howard and Childs (1959) proposed that the difference may be due to pocket gophers having individual variation in their susceptibility to strychnine by developing a tolerance for the toxicant after repeated exposure. This factor may have been observed in strychnine laboratory feeding trails conducted at NWRC (G.H. Matschke, unpublished data, 1989). In a 3-day no-choice study, plains pocket gophers generally accepted baits with various amounts of strychnine alkaloid. Mcan bait consumption on Day 1 ranged from $2.7 \mathrm{~g}$ of $0.01 \%$ strychnine alkaloid to $0.2 \mathrm{~g}$ of $1.51 \%$. All gophers that died consumed bait on only 1 day; whereas, pocket gophers that survived consumed the baits on each of the 3 days. Some pocket gophers showed a tolerance to strychnine alkaloid baits; $45(18.0 \%)$ of the 250 gophers survived after feeding on strychnine bait concentrations that ranged from $0.20 \%$ to $1.0 \%$. However, the number of survivors declined to 2 $(3.3 \%)$ of 59 after feeding on strychnine-bait concentrations of $1.2 \%$ or greater.

Unfortunately, data on the consumption of the strychnine alkaloid baits by pocket gophers in field studies are sparse. 
Table !

Strychnine percent mortality based on least-squares (LS) mean residues in the carcasses of plains pocket gophers following hand-baiting with $0.0 \%, 0.35 \%, 0.75 \%$, or $1.30 \%$ concentrations of strychnine alkaloid bait

\begin{tabular}{|c|c|c|c|c|}
\hline $\begin{array}{l}\text { Strychnine } \\
\text { concentrations }\end{array}$ & Fate of gophers & Treatment units & $\begin{array}{l}\text { Strychnine LS } \\
\text { means (ppm) }\end{array}$ & $\begin{array}{l}\text { Strychnine } \\
\% \text { mortality }\end{array}$ \\
\hline \multirow{2}{*}{$0.0 \%$} & 27 survived & $2 \& 7$ & $<$ LOD $^{\mathrm{a}}$ & 0.0 \\
\hline & 2 died $^{b}$ & $2 \& 7$ & - & - \\
\hline Total & 29 gophers & $2 \& 7$ & $<\mathrm{LOD}^{\mathrm{a}}$ & $0.07^{\circ}$ \\
\hline \multirow[t]{4}{*}{$0.35 \%$} & 16 died & $4 \& 8$ & 5.03 & 66.7 \\
\hline & 1 survivor & 8 & 0.90 & \\
\hline & 7 survived & $4 \& 8$ & $<\mathrm{LOD}^{\mathrm{a}}$ & - \\
\hline & 6 died $^{\mathrm{b}}$ & $4 \& 8$ & - & - \\
\hline Total & 30 gophers & $4 \& 8$ & 4.85 & $73.3^{\mathrm{c}}$ \\
\hline \multirow[t]{2}{*}{$0.75 \%$} & 26 died & $3 \& 6$ & 8.04 & 96.3 \\
\hline & $1 \operatorname{died}^{b}$ & $3 \& 6$ & & - \\
\hline Total & 27 gophers & $3 \& 6$ & 8.04 & $100.0^{c}$ \\
\hline \multirow[t]{2}{*}{$1.30 \%$} & 26 died & $1 \& 5$ & 9.47 & 89.7 \\
\hline & 3 survived & $1 \& 5$ & $<\mathrm{LOD}^{\mathrm{a}}$ & - \\
\hline Total & 29 gophers & $1 \& 5$ & 9.47 & $89.7^{\circ}$ \\
\hline
\end{tabular}

${ }^{\mathrm{a}} \mathrm{LOD}=0.2 \mathrm{ppm}$.

${ }^{b}$ No data - the presence in chromatogram of an interfering peak of an unknown co-eluting compound masked the strychnine alkaloid peak and were deleted from all residuc analyses.

${ }^{\mathrm{c}}$ Total mortality equals strychnine mortality plus natural (unexplained) mortality.

Table 2

Comparative mortality of plains pocket gophers occurring in the current study and two unpublished NWRC studies by Matschke and Hegdal (1990) and results of a 3-day laboratory no choice feeding trial (Matschke and McCann, 1989)

\begin{tabular}{llll}
\hline Nominal strychnine-bait concentration & Percent mortality & Percent mortality & Percent mortality \\
\hline & Matschke and Hegdal (1990) & Current study & Matschke and McCann (1989) \\
$0.0 \%$ & (burrow builder) & (hand-baiting) & (laboratory) \\
$0.35 \%$ & 17 & 7 & -13 \\
$0.75 \%$ & 87 & 100 & 80 \\
$1.30 \%$ & 94 & 90 & $97^{a}$ \\
\hline
\end{tabular}

${ }^{a}$ Strychnine concentration was $1.16 \%$.

In our study, we found 1 of 8 surviving pocket gophers had consumed the $0.35 \%$ strychnine bait. This survivor had a $0.9 \mathrm{ppm}$ residue level, that was less than the lowest detected strychnine residue level (1.2 ppm) among the 16 gophers that died on the same $(0.35 \%)$ TUs. Strychnine residues, if present, in the other 7 surviving pocket gophers were below the LOD $(0.2 \mathrm{ppm})$.

Taste aversion also may have occurred in the current study at the highest strychnine concentration $(1.30 \%)$, because $3(10 \%)$ of the gophers survived from these TUs. However, another explanation of their survival was whether there was a sufficient amount of bait placed within each burrow system. If a marking agent had been incorporated with the strychnine alkaloid baits, additional data might have been obtained about whether survivors found the bait, covered, transported, or consumed it.

We did not observe non-target mortality associated with the strychnine-laced carcasses. Probably, because all carcasses were at least $15 \mathrm{~cm}$ underground in extensive burrow systems. Also, we documented no non-target mortality during the daily above-ground searches for animal carcasses and during the extensive radio-tracking activities on each TU.

\section{Acknowledgements}

Special thanks go to our cooperator for his assistance in providing an ideal study site. The first author owes special thanks to Kathleen A. Fagerstone, Michael W. Fall, Ray T. Sterner, and Stephen A. Shumake who provided valuable reviews of this paper. Field support was provided by Stephen A. Shumake, John W. Theade, Kenneth L. Tope, and Steven J. Greiner. Analytical chemistry support was provided by Margaret J. Godall; bait formulation was provided by Melvin V. Garrison and the late Jerry D. Roberts. Gophers used 
in this study were maintained and tested according to approved protocols and animal welfare standards. The use of trade names does not constitute endorsement by the Federal Government.

\section{References}

Buck, W.B., 1991. Toxicity of pesticides in livestock. In: Pimental (ed.), Handbook of Pest Management in Agriculture, Vol. II. CRC Press, Inc., Boca Raton, FL, pp. 571-587.

Howard, W.E., Childs Jr., H.E.. 1959. Ecology of pocket gophers with emphasis on Thomomys hotuce mea. Hilgardia 29, 277-355.

Ramey, C.A.. Schafer Jr., E.W.. Fagerstone, K.A.. Palmateer, S.D. 1994. Active ingredients in APHIS's vertebrate pesticides use and reregistration status. Proceedings of the Vertebrate Pest Conference 16. $124-132$.
Richens. B.V., 1967. The status and use of gophacide. Proceedings of the Vertebrate Pest Conference 3, 118 125.

SAS Institute. 1966. SAS STAT User's Guide. SAS Institute Inc., Cary, NC.

Schneider, B.A., Hitch, R.K.. 1982. Pesticide assessment guidelines, subdivision G: Product performances. Guideline reference number 96 -12 (Rodenticide on farm and rangelands), p. 315.

Tickes, B.R., 1983. Gopher control in alfalfa. Proceedings Conference on the Alfalfa Symposium 13, 68-71.

Tickes, B.R., Cheath. L.K., Stair, J.L., 1982. A comparison of selected rodenticide for the control of the common valley gopher (Thomomys bottae). Proceedings of the Vertebrate Pest Conference 10, 201-204.

US Department of Agriculture, 1994. Animal Damage Control Program's Final Environmental Impact Statement. APIIIS, Washington. DC, Vol. 1 3. 1102pp.

US Environmental Protection Agency, 1996. Reregistration eligibility decision (RED) strychnine. Office of Pesticide Programs, Washington, DC, 133pp. 